COSTING:Journal of Economic, Business and Accounting

Volume 3 Nomor 2, Juni 2020

e-ISSN : 2597-5234

IDMEKpR

\title{
PERPUTARAN PIUTANG, PERPUTARAN MODAL KERJA, PERPUTARAN KAS DAN STRUKTUR MODAL TERHADAP PROFITABILITAS
}

\author{
RECEIVABLES TURNOVER, WORKING CAPITAL TURNOVER, CASH \\ TURNOVER AND CAPITAL STRUCTURE AGAINST PROFITABILITY
}

\author{
Bayu Wulandari ${ }^{1}$, Julyani ${ }^{2}$, Santi $^{3}$, Jessica Sulastio ${ }^{4}$, Lucianto Hanafie ${ }^{5}$ \\ Universitas Prima Indonesia ${ }^{1,2,3,4,5}$ \\ wulandari.bayu044@gmail.com ${ }^{1}$
}

\begin{abstract}
In the midst of an unstable Indonesian economy, it requires every company to be able to face and anticipate all situations to survive in increasingly fierce competition. This research aims to test whether receivables turnover, working capital turnover, cash turnover and capital structures have an influence on profitability in large and small trade sector manufacturing companies listed on the stock Exchange Indonesian. This research is a type of quantitative descriptive research which uses data from 62 companies manufacturing large and small trade sectors listed on the Indonesia Stock Exchange.The sampling method used in this study was purposive sampling and obtained as many as 18 samples. The research methods used are methods of descriptive analysis and analysis methods of multiple linear regression.The results showed that in a partial receivables turnover has no significant effect on profitability,working capital turnover has no negative and significant effect on profitability,cash turnover has no effect Significant impact on profitability and the capital structure has no significant effect on the profitability listed on the Indonesia Stock Exchange.Simultaneously the receivables turnover,working capital turnover,cash turnover and capital structure together have significant effect on the company's profitability measured from the profitability listed on the Indonesia Stock Exchange.
\end{abstract}

Keywords: Receivables Turnover, Working Capital Turnover, Cash Turnover, Capital Structure, and Profitability.

ABSTRAK
Ditengah perkenomian Indonesia yang tidak stabil, menuntut setiap perusahaan untuk
mampu menghadapi dan mengantisipasi segala situasi untuk tetap bertahan dalam
persaingan yang semakin ketat. Penelitian ini bertujuan untuk menguji apakah
perputaran piutang, perputaran modal kerja, perputaran kas dan struktur modal memiliki
pengaruh terhadap profitabilitas pada perusahaan manufaktur sector perdagangan besar
dan kecil yang terdaftar di Bursa Efek Indonesia. Penelitian ini merupakan jenis
penelitian deskriptif kuantitatif, yang menggunakan data dari 62 perusahaan manufaktur
sector perdagangan besar dan kecil yang terdaftar di Bursa Efek Indonesia. Metode
pengambilan sampel yang digunakan dalam penelitian ini adalah purposive sampling
dan diperoleh sampel sebanyak 18 sampel. Metode penelitian yang digunakan adalah
metode analisis deskriptif dan metode analisis regresi linear berganda. Hasil penelitian
menunjukkan bahwa secara parsial Perputaran piutang tidak berpengaruh signifikan
terhadap Profitabilitas, Perputaran modal kerja tidak berpengaruh negatif dan signifikan
terhadap Profitabilitas, Perputaran kas tidak berpengaruh signifikan terhadap 
Profitabilitas, dan Struktur modal tidak berpengaruh signifikan terhadap Profitabilitas yang terdaftar di Bursa Efek Indonesia. Secara simultan Perputaran Piutang, Perputaran Modal Kerja, Perputaran Kas dan Struktur Modal bersama-sama berpengaruh signifikan terhadap Profitabilitas perusahaan diukur dari profitabilitas yang terdaftar di Bursa Efek Indonesia.

Kata Kunci: Perputaran Piutang, Perputaran Modal Kerja, Perputaran Kas, Struktur Modal, Profitabilitas.

\section{PENDAHULUAN}

$\begin{array}{ccr}\text { Pada hakikatnya, } & \text { setiap } \\ \text { perusahaan yang didirikan oleh }\end{array}$ seseorang atau pun sekumpulan orang, memperoleh keuntungan atau laba yang maksimal merupakan tujuan utama. Ditengah perkenomian Indonesia yang tidak stabil, menuntut setiap perusahaan untuk mampu menghadapi dan mengantisipasi segala situasi untuk tetap bertahan dalam persaingan yang semakin ketat. Oleh karena itu, maka diperlukan manajemen yang baik untuk mengolah kegiatan perusahaan menjadi lebih efektif dan efisien. Dalam meningkatkan jumlah penjualan, biasanya perusahaan akan menjual barang dagangan secara kredit ke pada konsumen. Jika penjualan secara kredit meningkat, maka jumlah piutang usaha juga akan meningkat. Namun peningkatan piutang yang tidak terkontrol akan menimbulkan risiko terhambatnya kegiatan operasional perusahaan dalam mengejar keuntungan. Misalnya, perusahaan menjual dagangan dengan nilai piutang yang lebih besar, maka perusahaan terpaksa membayar hutang menggunakan modal kerja perusahaan yang artinya kesempatan untuk meningkatkan profitabilitas (Budiansyah, 2015).

Selain itu, untuk kemampuan perusahaan dalam menghasilkan laba dapat diukur dengan melihat kesuksesan dan kemampuan perusahaan dalam menggunakan aktivanya secara produktif. Modal kerja merupakan salah satu komponen terpenting dari aktiva yang harus dikelola dan dimanfaatkan secara efektif dan produktif sehingga mampu meningkatkan profitabilitas

Struktur modal merupakan paduan sumber dana jangka panjang yang digunakan oleh perusahaan. Strutur modal itu sendiri menunjukkan jumlah modal dan hutang yang dimiliki oleh perusahaan yang digunakan untuk menjalankan aktivitas perusahaan. Sehingga jumlah hutang tidak boleh lebih besar dibandingkan dengan penggunaan modal itu sendiri karena akan berisiko mengalami kebangkrutan (Astuti et al., 2015).

Tabel 1 Kondisi Keuangan Perusahaan APII tahun 2016-2017

\begin{tabular}{|c|c|c|c|c|c|c|}
\hline $\begin{array}{l}\text { Kode } \\
\text { Emiten }\end{array}$ & Tahun & Piutang & $\begin{array}{c}\text { Penjualan } \\
\text { Bersih }\end{array}$ & $\begin{array}{c}\text { Modal } \\
\text { KerjaBersih } \\
\end{array}$ & Total Hutang & Laba \\
\hline & 2014 & 77.925 .322 .395 & 256.881 .565 .791 & 77.869 .359 .322 & 227.470 .609 .783 & 31.956 .766 .696 \\
\hline \multirow[t]{4}{*}{ APII } & 2015 & 59.565 .901 .580 & 202.115 .388 .442 & 80.041 .940 .385 & 201.261 .992 .817 & 16.531 .392 .774 \\
\hline & 2016 & 48.198 .758 .542 & 170.213 .172 .087 & 79.064 .835 .585 & 168.731 .948 .348 & 15.871 .882 .915 \\
\hline & 2017 & 52.059 .260 .606 & 168.065 .942 .352 & 81.744 .323 .506 & 175.788 .682 .046 & 13.921 .992 .681 \\
\hline & 2014 & 563.193 .000 .000 & 11.026 .638 .000 .000 & 528.735 .000 .000 & 1.813 .516 .000 .000 & 254.019 .000 .000 \\
\hline \multirow[t]{3}{*}{ TURI } & 2015 & 680.592 .000 .000 & 10.157 .265 .000 .000 & 522.612 .000 .000 & 1.981 .471 .000 .000 & 292.222 .000 .000 \\
\hline & 2016 & 690.456 .000 .000 & 12.453 .772 .000 .000 & 493.353 .000 .000 & 2.155 .109 .000 .000 & 552.456 .000 .000 \\
\hline & 2017 & 705.608 .000 .000 & 12.917 .257 .000 .000 & 654.424 .000 .000 & 2.327 .069 .000 .000 & 476.203 .000 .000 \\
\hline
\end{tabular}




\begin{tabular}{|c|c|c|c|c|c|c|}
\hline & 2014 & 488.372 .744 & 10.673 .929 .378 & 1.320 .200 .544 & 6.167 .969 .848 & 78.207 .644 \\
\hline \multirow[t]{3}{*}{ MAPI } & 2015 & 568.002 .842 & 11.620 .751 .764 & 2.405 .667 .143 & 6.508 .024 .000 & 30.095 .070 \\
\hline & 2016 & 578.010 .534 & 12.729 .191 .758 & 2.434 .951 .653 & 6.479 .927 .515 & 208.475 .635 \\
\hline & 2017 & 708.664 .183 & 14.765 .635 .149 & 22.338 .277 .684 & 7.182 .975 .931 & 350.081 .265 \\
\hline \multirow{4}{*}{ RALS } & 2014 & 23.306 .000 .000 & 5.131 .375 .000 .000 & 1.727 .400 .000 .000 & 1.240 .243 .000 .000 & 355.663 .000 .000 \\
\hline & 2015 & 33.612 .000 .000 & 4.788 .667 .000 .000 & 1.870 .282 .000 .000 & 1.241 .100 .000 .000 & 336.054 .000 .000 \\
\hline & 2016 & 51.726 .000 .000 & 5.092 .752 .000 .000 & 1.821 .834 .000 .000 & 1.309 .610 .000 .000 & 408.479 .000 .000 \\
\hline & 2017 & 57.122 .000 .000 & 4.786 .508 .000 .000 & 2.044 .856 .000 .000 & 1.397 .577 .000 .000 & 406.580 .000 .000 \\
\hline
\end{tabular}

Sumber : APII (2019

Pada tabel di atas menjekaskan bahwa piutang pada perusahaan APII tahun 2016-2017 mengalami kenaikan sementara laba mengalami penurunan, bertolak belakang dengan teori yang menyatakan bahwa jika piutang meningkat maka laba akan naik. Penjualan bersih perusahaan TURI pada tahun 2016-2017 menjelaskan bahawa penjualan bersih naik namun laba mengalami penurunan, hal ini bertolak belakang dengan teori dimana teori menyatakan jika penjualan bersih mengalami kenaikan maka laba bersih mengalami kenaikan juga. Modal kerja perusahaan RALS pada tahun 20162017 mengalami kenaikan sedangkan laba mengalami penuruanan, bertolak belakang dengan teori yang menyatakan bahwa penjualan naik maka laba seharusnya naik juga sedangkan untuk hutang perusahaan MAPI pada tahun 2016-2017 mengalami kenaikan sedangkan laba mengalami kenaikan juga, hal ini juga bertolak belakang dengan teori yang menyatakan bahwa jika hutang naik maka laba akan menurun.

Semakin tinggi rasio perputaran piutang usaha menunjukan bahwa modal kerja yang tertanam dalam piutang usaha semakin kecil dan hal ini berarti semakin baik bagi perusahaan (Hery, 2017). Rasio ini menunjukkan berapa cepat penagihan piutang makin besar semakin baik karena penagihan piutang dilakukan dengan cepat. Analisis piutang penting karena dampaknya terhadap posisi aktiva dan arus laba perusahaan. Kedua dampak ini saling terikat. Pengalaman menunjukan bahwa perusahaan tidak dapat menagih semua piutangnya. Kerugian piutang dapat menjadi sangat berarti dan mempengaruhi baik aktiva lancer serta laba bersih sekarang dan masa depan (Budiansyah et al., 2015). Penelitian oleh Budiansyah et al., (2015) dan Surya et al., (2017) menunukkan bahwa perputaran piutang berperan penting dan signifikan terhadap profitabilitas perusahaan.

Dengan jumlah pengeluaran setiap harinya yang tetap, tetapi dengan makin lamanya periode perputaran, maka jumlah modal kerja yang dibutuhkan adalah makin besar. Penelitian oleh Santono (2016) tentang pengaruh perputaran modal kerja terhadap profitabilitas menemukan bahwa Perputaran modal kerja mengukur efektifitas penggunaan aktiva lancer untuk menghasilkan penjualan. Perputaran modal kerja diukur dengan Working Capital Turnover Ratio yang berdasarkan perbandingan penjualan yang dihasilkan dengan aktiva lancer semakin tinggi rasio perputaran modal kerja maka semakin baik. kinerja suatu perusahaan dimana persentase modal kerja yang ada mampu menghasilkan penjualan dengan jumlah tertentu. Semakin besar rasio ini menunjukkan efektifnya pemanfaatan modal kerja yang tersedia dalam meningkatkan profitabilitas perusahaan. Penelitian lainnya juga mendukung penelitian sebelumnya oleh Santono (2016) yaitu oleh Jauhari (2016) dimana perputaran 
modal kerja yang baik dalam suatu perusahaan mampu meningkatkan profitabilitas perusahaan.

Faktor selanjutnya yang memperngaruhi profitabilitas adalah perputaran kas. Apabila rasio perputaran kas tinggi, ini berarti, ketidakmampuan perusahaan dalam membayar tagihan. Sebaliknya apabila rasio perputaran kas rendah, dapat diartikan kas yang tertanam pada aktiva yang sulit dicarikan dalam waktu singkat sehingga perusahaan harus bekerja kerja dengan kas yang lebih sedikit. Penelitian oleh Santono (2016) menyatakan bahwa Perputaran kas (cash turnover) adalah berapa kali uang kas berputar dalam satu periode tertentu melalui penjualan. Perputaran kas yang semakin tinggi akan semakin baik, karena ini menunjukan semakin efisiensi didalam penggunaan kas. Perputaran kas yang berlebih-lebihan dengan modal kerja yang tersedia terlalu kecil, akan mengakibatkan kurang dapat memenuhi kebutuhan perusahaan. Demikian seharusnya, dengan kas semakin rendahnya perputaran kas mengakibatkan banyaknya uang kas yang tidak produktif sehingga akan mengurangi probabilitas perusahaan.

Pada kondisi ekonomi yang memburuk pada umumnya suku bunga pinjaman sangat tinggi, sementara penjualan dan laba perusahaan menurun. Hal ini mengakibatkan kemampuan perusahaan untuk menghasilkan laba dengan menggunakan utang lebih kecil dari pada tingkat bunga yang harus dibayar oleh perusahaan. Semakin besar proporsi utang pada struktur modal suatu perusahan, makin tinggi beban tetap dan komitmen pembayaran kembali yang ditimbulkan. Kemungkinan perusahaan tidak mampu membayar bunga dan pokok pinjaman saat jatuh tempo dan kemungkinan kreditor mengalami kerugian juga turut meningkat (Languju, 2016). Utang yang terlalu besar menghambat inisiatif dan fleksibilitas manajemen untuk mengejar kesempatan yang mengutungkan.

Berdasarkan beberapa konsep teoretis dan penelitian terdahulu terkait perputaran piutang, modal kerja, perputaran kas dan struktur modal terhadap profitabilitas yang dalam hal ini di ukur melauli rasio return on asset maka pentingnya melakukan penelitian ini adalah untuk menguji kembali pengaruh variabel-variabel tersebut pada ROA perusahaan manufaktur sektor perdagangan besar dan kecil yang terdaftar di Bursa Efek Indonesia.

\section{METODE PENELITIAN \\ Populasi dan Sampel}

Populasi merupakan wilayah generalisasi yang terdiri atas obyek/subyek yang mempunyai kualitas dan karakteristik tertentu yang diterapkan oleh peneliti untuk dipelajari dan kemudian ditarik kesimpulannya. Jadi populasi bukan hanya orang, tetapi juga obyek dan benda-benda alam yang lain. Populasi juga bukan hanya sekedar jumlah yang ada pada obyek atau subyek yang telah dipelajari, tetapi meliputi seluruh karakteristik atau sifat yang dimiliki oleh subyek atau obyek itu.

Sampel merupakan bagian dari jumlah dan karakteristik yang dimiliki oleh populasi tersebut. Teknik pengambilan sampel dalam penelitian ini adalah berdasarkan purposive sampling. Total jumlah data pada sampel yang digunakan dalam penelitian ini yaitu sebanyak 72 data pengamatan, yang diambil dari jumlah sampel 18 perusahaan dikalikan dengan 4 tahun penelitian. 


\section{Teknik Pengumpulan Data}

Metode pengumpulan data dalam penelitian ini dilakukan dengan studi dokumentasi yang merupakan teknik pengumpulan data dengan cara mencatat, mengumpulkan, dan mempelajari data-data perusahaan terkait masalah yang sedang diteliti mengenai perputaran piutang, perputaran modal kerja, perputaran kas, dan struktur modal setiap sampel diambil dari laporan keuangan perusahaan sub sector perdagangan besar dan perdagangan eceran yang dipublikasi di Bursa Efek Indonesia sejaktahun 2014-2017.

\section{Jenis dan Sumber Data Penelitian}

Data yang digunakan dalam penelitian inimerupakan data sekunder. Data sekunder merupakan data yang sudah tersedia dan dikumpulkan oleh pihak lain. Data sekunder dalam penelitian ini meliputi profil perusahaan, strukturor ganisasi dan data yang diperoleh dari hasil pengolahan buku, teori-teori dan data yang berhubungan dengan masalah yang diteliti, Data sekunder tersebut di peroleh dari situs www.idx.co.id dalam bentuk laporan keuangan perusahaan sampel yang dipublikasikan.

\section{Model Analisis Data Penelitian Model Penelitian}

Dalam penelitian ini, metode analisis data yang digunakan adalah metode analisis statistik. Sebelum data dianalisis, maka untuk keperluan analisis data tersebut, terlebih dahulu dilakukan uji asumsi klasik sebelummelakukanpengujianhipotesis.

Analisis data dalammengelolah data menggunakan SPSS (Statistical Product and Service Solution).

$$
\text { Model analsisis data }
$$

inimenggunakan analisis regresi

berganda untuk mengetahui pengaruh variable bebas (independen) dan variabel terikat (dependen) digunakan rumusan analisis regresi linier berganda sebagaiberikut:

$$
\begin{array}{ll}
\mathrm{Y}=\mathrm{a}+\mathrm{b} 1 \mathrm{X} 1+\mathrm{b} 2 \mathrm{X} 2+\mathrm{b} 3 \mathrm{X} 3+\mathrm{b} 4 \mathrm{X} 4 \\
+\mathrm{e} \\
\text { Keterangan: } & \\
\mathrm{Y} & =\text { Profitabilitas } \\
\mathrm{A} & =\text { Konstanta } \\
\mathrm{b} 1, \mathrm{~b} 2, \mathrm{~b} 3, \mathrm{~b} 4 & =\text { Keadaan Regresi } \\
\mathrm{X} 1 & =\text { Variabel Perputaran Piutang } \\
\mathrm{X} 2 & =\text { Variabel Perputaran Modal } \\
\text { Kerja } & \\
\mathrm{X} 3 & =\text { Variabel Perputaran Kas } \\
\mathrm{X} 4 & =\text { Variabel Struktur Modal } \\
\mathrm{e} & =\text { Estimasi Kesalahan }(0,05)
\end{array}
$$

\section{Statistik Deskriptif}

Sampel (N) pada penelitian ini adalah laporan keuangan Perusahaan manufaktur di Bursa Efek Indonesia daritahun 2014-2017 sehingga data penelitian berjumlah 72 sampel. Hasil pengolahan data sampel dapat dilihat dari statistik deskriptif di bawahini :

1. Variabel perputaran piutang memiliki jumlah sampel sebanyak 72 , dengan nilai minimum 2,77 yaitu PT. Colorpak Indonesia Tbk di tahun 2015 dan nilai maksimum 293,72 yaitu PT. Ace Hardware Indonesia Tbk di tahun 2015.

2. Variabel perputaran modal kerja memiliki jumlah sampel sebanyak 72, dengan nilai minimum 0,68 yaitu PT. Arita Prima Indonesia Tbk di tahun 2017 dan nilai maksimum 24,06 yaitu PT. FKS Multi AgroTbk di tahun 2014.

3. Variabel perputaran kas memiliki jumlah sampel sebanyak 72, dengan nilai minimum 0,66 yaitu PT. Mitra Adi perkasaTbk di tahun 2017 dan nilai maksimum 429144,27 yaitu PT. FKS Multi AgroTbk di tahun 2015.

4. Variabelstruktur modal memilikijumlahsampelsebanyak 72 , dengannilai minimum 0,09 yaitu 
PT. Mitra Komunikasi Nusantara Tbkditahun 2015 dan nilaimaksimum 3,90 yaitu PT. FKS Multi AgroTbk di tahun 2015.

5. Variabel profitabilitas memiliki jumlah sampel sebanyak 72, dengan nilai minimum 0,00 yaitu PT. Tiga raksa SatriaTbk di tahun 2014 dan nilai maksimum 0,41 yaitu PT.Wicakana Overseas International di tahun 2017.

\section{HASIL DAN PEMBAHASAN Model Penelitian}

Pengujian hipotesis yang digunakan dalam penelitian adalah dengan menggunakan analisis regresi linier berganda. Model regresi yang digunakan adalah sebagai berikut.

Tabel 2. Hasil Regresi Linear Berganda

\begin{tabular}{lrr}
\hline & \multicolumn{2}{c}{ Coefficients $^{\mathbf{a}}$} \\
\cline { 2 - 3 } Model & \multicolumn{2}{c}{ Unstandardized Coefficients } \\
\cline { 2 - 3 } (Constant) & \multicolumn{1}{c}{ B } & Std. Error \\
\hline LN_RTO & 3,750 &, 360 \\
\hline LN_Perputaran & -212 &, 111 \\
Modal Kerja &, 493 &, 190 \\
\hline LN_Perputaran & & \\
Kas &, 164 &, 046 \\
\hline LN_Struktur & - & \\
Modal &, 657 &, 212 \\
\hline Sumber : Data olahan $(2019)$ &
\end{tabular}

$\mathrm{ROA}=(-3,750)+0,212 \mathrm{RTO}+(-0,493)$ perputaran modal kerja $+0,164$ perputaran kas $+(-0,657)$ struktur modal

\section{Koefisien Determinasi $\left(\mathbf{R}^{2}\right)$}

$$
\text { Koefisien }
$$$$
\text { determinasi }
$$

ditujukan untuk mengetahui seberapa besar kemampuan model dalam menerangkan variabel terikat. Jika koefisien determinasi $\left(\mathrm{R}^{2}\right)$ semakin besar atau mendekati 1, makadapat dikatakan bahwa kemampuan variabelbebas (X) adalah besar terhadap variabel terikat (Y).
Tabel 3 Uji R R $^{2}$

\begin{tabular}{lrll}
\hline & & Adjusted & \multicolumn{1}{l}{$\begin{array}{l}\text { Std. Error } \\
\text { of } \\
\text { the }\end{array}$} \\
Model R & R Square & Square & Estimate \\
\hline $1 \quad, 660^{\mathrm{a}}$ &, 435 &, 402 & 1,00670 \\
\hline Sumber : data olahan (2019) & &
\end{tabular}

Berdasarkan Tabel 3 di atas menunjukkan hasil Uji Koefisien Determinasi diperoleh nilai Adjusted $R$ Square koefisien determinasi sebesar 0,402 yang berarti $40,2 \%$ dari variasi variabel return on asset yang dapat dijelaskan oleh variabel independen RTO, perputaran modal kerja,perputaran kas, struktur dan struktur modal sedangkan sisanya $59,8 \%$ dijelaskan oleh variabel bebaslainnya yang tidak teliti dalam penelitian ini contohnya penjualan, biaya operasional dan lainnya.

\section{Pengujian Hipotesis Secara Simultan}

Uji F digunakan untuk menunjukkan apakah semua variabel independen yang dimasukkan dalam model mempunyai pengaruh secara bersama-sama terhadap variabel dependen. Berdasarkan hasil pengolahan data dengan program SPSS maka diperoleh hasil sebagai berikut :

\section{Tabel 4. Uji F}

\begin{tabular}{|c|c|c|c|c|}
\hline & $\begin{array}{lr}\text { Sum of } & \text { D } \\
\text { Squares } & \text { f }\end{array}$ & $\begin{array}{l}\text { Mean } \\
\text { Square }\end{array}$ & $\mathrm{F}$ & Sig. \\
\hline Regression & $\begin{array}{ll}52,328 & 4\end{array}$ & 13,082 & 12,908 &, $000^{\mathrm{b}}$ \\
\hline Residual & $67,901 \quad 67$ & 1,013 & & \\
\hline Total & 120,22971 & & & \\
\hline
\end{tabular}

Sumber : Data olahan (2019)

Dari tabel diatas, dapat dilihat bahwa nilai $\mathrm{F}$ hitung sebesar 12,908 dan nilai Ftabel dengan nilai signifikan 0,05 dan dilihat df1 dan df2 nya dengan rumus df $1=\mathrm{k}-1=(4+1)-1=4$, df $2=\mathrm{n}-\mathrm{k}$ $=72-4=68$ adalah sebesar 2,51, maka nilai Fhitung $>$ Ftabel $(12,908>2,51)$ 
sehingga hasil penelitian menolak Ho dan menerima Ha serta nilai signifikan lebih kecil dari $0,05(0,000<0,05)$.

Dengan demikian dapat disimpulkan bahwa variabel perputaran piutang, perputaran modal kerja, perputaran kas, dan struktur modal berpengaruh signifikan terhadap profitabilitas perusahaan pada perusahaan manufaktur sub sector perdagangan besar dan kecil yang terdaftar di Bursa Efek Indonesia (BEI). Alasan penelilti menggunkan LN dalam penelitian ini adalah untuk menormalkan data adalah dengan menggunakan logaritma natural (LN).

\section{Pengaruh Perputaran Piutang Terhadap Profitabilitas}

Dari hasil pengujian secara parsial, dapat dilihat bahwa variabel perputaran piutang memiliki nilai $t$ hitung sebesar 1,910 $\mathrm{t}$ tabel sebesar $\mathrm{t} d \mathrm{df}$ $=72$, diperoleh $\mathrm{t}$ tabel sebesar 1,666. Maka t hitung $<\mathrm{t}$ tabel $(1,910<1,666)$ dengan nilai signifikan $0,060>0,05$ hal ini menunjukkan bahwa hasil hipotesis penelitian dimana Ho diterima dan $\mathrm{Ha}$ ditolak artinya perputaran piutang secara parsial berpengaruh tidak signifikan terhadap profitabilitas perusahaan pada perusahaan manufaktur sub sector perdagangan besar dan kecil yang terdaftar di Bursa Efek Indonesia (BEI). Hasil penelitian ini tidak sejalan dengan hasil penelitian sebelumnya oleh Budiansyah et al., (2015) dan Surya et al., (2017) menunukkan bahwa perputaran piutang berperan penting dan signifikan terhadap profitabilitas perusahaan. Namun hasil penelitian sejalan dengan Nurafika (2018) dimana perputaran piutang juga tidak berpengaruh signifikan terhadap profitabilitas perusahaan.

\section{Pengaruh Perputaran Modal Kerja Terhadap Profitabilitas \\ Dari hasil pengujian secara} parsial, dapat dilihat bahwa variabel perputaran modal kerja memiliki nilait hitung sebesar $-2,601 \mathrm{t}$ tabel sebesar $\mathrm{t} d \mathrm{ff}$ $=72$, diperoleh $\mathrm{t}$ tabel sebesar 1,666. Maka t hitung>ttabel $(-2,601<1,666)$ dengan nilai signifikan $0,011>0,05$ hal ini menunjukkan bahwa hasil hipotesis penelitian dimana Ho diterima dan $\mathrm{Ha}$ ditolak artinya perputaran modal kerja

Secara parsial berpengaruh tidak signifikan terhadap profitabilitas perusahaan pada perusahaan manufaktur sub sector perdagangan besar dan kecil yang terdaftar di Bursa Efek Indonesia (BEI). Hasil penelitian ini bertolak belakang dengan penelitian yang dilakukan oleh Santono (2016) dan Jauhari (2016) dimana perputaran modal kerja yang baik dalam suatu perusahaan mampu meningkatkan profitabilitas perusahaan.

\section{Pengaruh Perputaran Kas Terhadap Profitabilitas}

Dari hasil pengujian secara parsial, dapat dilihat bahwa variabel perputaran kas memiliki nilai t hitung sebesar 3,541 t tabel sebesar $\mathrm{t} d f=72$, diperoleh $\mathrm{t}$ tabel sebesar 1,666. Maka $\mathrm{t}$ hitung $<\mathrm{t}$ tabel $(3,541>1,666)$ dengan nilai signifikan $0,001<0,05$ hal ini menunjukkan bahwa hasil hipotesis penelitian dimana Ha diterima dan Ho ditolak artinya perputaran kas secara parsial berpengaruh signifikan terhadap profitabilitas perusahaan pada perusahaan manufaktur sub sector perdagangan besar dan kecil yang terdaftar di Bursa Efek Indonesia (BEI). Hasil penelitian ini sejalan dengan penelitian yang dilakukan oleh Santono (2016) dimana perputaran kas yang baik dalam perusahaan berpengaruh signifikan terhadap profitabilitas perusahaan. 


\section{Pengaruh Struktur Modal Terhadap Profitabilitas}

Dari hasil pengujian secara parsial, dapat dilihat bahwa variabel struktur modal memiliki nilai $\mathrm{t}$ hitung sebesar $-3,091 \mathrm{t}$ tabel sebesar $\mathrm{t}$ df $=72$, diperoleh $\mathrm{t}$ tabel sebesar 1,666. Maka $\mathrm{t}$ hitung <t tabel $(-3,091<1,666)$ dengan nilai signifikan $0,003<0,05$ hal ini menunjukkan bahwa hasil hipotesis penelitian dimana Ho diterima dan $\mathrm{Ha}$ ditolak artinya perputaran piutang secara parsial berpengaruh tidak signifikan terhadap profitabilitas perusahaan pada perusahaan manufaktur sub sector perdagangan besar dan kecil yang terdaftar di Bursa Efek Indonesia (BEI).

\section{PENUTUP}

\section{Kesimpulan}

Dari hasil penelitian ini diperoleh kesimpulan sebagaiberikut :

1. Perputaran Piutang secara parsial berpengaruh negatif dan tidak signifikan terhadap profitabilitas pada perusahaan sub sector perdagangan besar dan perdagangan kecil yang terdaftar di Bursa Efek Indonesia, sehingga hipotesis pertama $\left(\mathrm{H}_{1}\right)$ pada penelitian ini diterima dan hal ini mengindikasikan bahwa kenaikan atau penurunan struktur modal dapat mempengaruhi profitabilitas peusahaan.

2. Struktur Modal secara parsial berpengaruh positif dan signifikan terhadap profitabilitas pada perusahaan sub sector perdagangan besar dan perdagangan kecil yang terdaftar di Bursa Efek Indonesia, sehingga hipotesis keempat $\left(\mathrm{H}_{4}\right)$ pada penelitian ini diterima dan hal ini mengindikasikan bahwa kenaikan atau penurunan struktur modal dapat mempengaruhi profitabilitas perusahaan.
3. Perputaran piutang, perputaran modal kerja, perputaran kas dan struktur modal secarasimultan berpengaruh signifikan terhadap profitabilitas pada perusahaan sub sector perdagangan besar dan perdagangan kecil yang terdaftar Bursa Efek Indonesia, dengan koefisien determinasi25,3\%. Hal ini mengindikasikan bahwahi potesis $\operatorname{kelima}\left(\mathrm{H}_{5}\right)$ diterima.

\section{Saran}

Berdasarkan hasil penelitian, disarankan kepada perusahaan sub sector perdaganganbesar dan perdagangan kecil yang terdaftar di Bursa Efek Indonesia (BEI) untuk terusmenerus mempertahankan laba, dikarenakan laba dapat memberikan efek pada perusahaan yang dihasilkan oleh perusahaan sehingga dampaknya tersebut juga dapat dirasakan dalam menunjang kesejahteraan karyawan dalam perusahaan. Selain itu, perusahaan perlu memperhatikan efisiensi dari perputaran piutang, perputaran modal kerja, perputaran kas, dan struktur modal dapat lebih meningkatkan profitabilitas pada perusahaan.

\section{DAFTAR PUSTAKA}

Astuti, K. D., Retnowati, W., \& Rosyid, A. (2015). Pengaruh Struktur Modal Terhadap Profitabilitas. JAK (Jurnal Akuntansi): Kajian Ilmiah Akuntansi, 2(1).

Budiansyah, O., Safitri, Y., \& D.,W, C. (2015). Pengaruh Perputaran Kas, Perputaran Piutang, dan Perputaran Persediaan Terhadap Profitabilitas. 
Hery. (2017). Kajian Riset Akuntansi Mengulas Berbagai Hasil Penelitian Terkini dan Penerapannya. Cetakan kedua. Jakarta. CV.MandorMaju

Jauhari, A. (2016). Pengaruh Perputaran Modal Kerja Terhadap Profitabilitas. JMK (Jurnal Manajemen dan Kewirausahaan), 1(1), 22-30.

Languju, O. (2016). Pengaruh Return On Equity, Ukuran Perusahaan, Price Earning Ratio dan Struktur Modal terhadap Nilai Perusahaan Property and real estate terdaftar di Bursa Efek Indonesia. Jurnal Berkala Ilmiah Efisiensi, 16(2).

Nurafika, R. A. (2018). Pengaruh Perputaran Kas, Perputaran Piutang, Perputaran Persediaan Terhadap Profitabilitas Pada Perusahaan Semen. Jurnal Akuntansi Dan Bisnis: Jurnal Program Studi Akuntansi, 4(1).

Surya, S., Ruliana, R., \& Soetama, D. R. (2017). Pengaruh Perputaran Kas dan Perputaran Persediaan TerhadapProfitabilitas. Akuntab as, 10(2), 313-332.

Santono, C. B. (2016). Faktor-Faktor yang memperngaruhi profitabilitas pada perusahan Semen yang Terdaftar pada Bursa Efek Indonesia Tahun 2002-2010. Jurnal Dimensi, 1(1). 